\title{
ON THE ROLE OF CREATIVE ACTIVITIES IN MOTHER TONGUE TEXTBOOKS FOR UZBEK CLASSES IN THE DEVELOPMENT OF STUDENT'S THINKING
}

\author{
Ataullo Rakhmatovich Akhmedov
}

Phd, Uzbek Linguistics Faculty, Bukhara State University

Shokhida Yusufovna Yokubova

Master Degree Of Linguistics (Uzbek Language), 35th School Of Bukhara City

\section{ABSTRACT}

The article explores conclusions based on the study of primary school textbooks, the role of mother tongue education for uzbek classes in the effectiveness of education, the role of cognitive-pragmatic approach in mother tongue education and its contribution to expand the scope of student's thinking and creative exercises.

KEYWORDS:- Cognitive-pragmatic method, induction, the essence of mother tongue education, textbooks, language materials, the purpose of education, the effectiveness of education.

\section{INTRODUCTION}

Reforms in bringing the education system to a new level of quality in our country have created the necessary conditions for the formation of the need for students to acquire knowledge in the basics of science from primary education, spiritual and moral qualities based on basic national and universal values, labor skills and creative thinking and conscious attitude to the environment. The renewal of the content of the mother tongue in a cognitive-pragmatic way is creating need for improvement of pedagogical approaches. Today, special attention is paid to the quality and effectiveness of mother tongue education for uzbek classes in secondary schools. Special attention is paid to the design of creative activities of students, targeted research, taking into account the age characteristics of students. This involves updating the content of the mother tongue in a cognitive-pragmatic way.

"The provision of language materials in mother tongue programs and textbooks is closely linked to the effectiveness of the lessons. The acquisition of certain knowledge is crucial in mother tongue lessons. If the main goal of mother tongue lessons is to form and develop certain skills, the most effective method is analysis (induction). 1,

The research around the world on linguistic bases of cognitive-pragmatic updating of the content of mother tongue in the world, development of students' personality, development of their abilities, moral and aesthetic feelings, interest and desire to read, formation of emotional attitude to himself and

\footnotetext{
${ }^{1}$ Gulomov A., Nematov H. Ona tili ta'limi mazmuni. - T .: "O’qituvchi" Publishing House, 1995.
} 
the world around him which is based on development of educational structures is being conducted on pedagogical technologies in order to help to realize the intellectual potential of the student. Cognitive-pragmatic updating of the content of the mother tongue in the subject of conceptual scientific research aimed at creative activity, interest in discovery, quick comprehension of the figurative content of fairy tales, stories, songs, music and creative skills are being carried out.

Cognitive-pragmatic (inductive) method is a method of generating knowledge from observation and analysis to the law, from specificity to generality. This method approaches the learner as a manager, an organizer of the learning process. Therefore, in the educational process, research is mainly done by the learner ${ }^{2}$. Cognitive-pragmatic updating of textbook content means that students make their own rules by doing exercises in mother tongue textbooks. The following types of partially creative and creative exercises can be used in mother tongue textbooks for uzbek classes.

For 1st grade mother tongue textbook:

1. What words can be formed by substituting vowels instead of dots? B.l.m, b.l.k., k.ch.k

2. Students (b.l.m) find that words such as knowledge, section, child are formed. This will strengthen students' phonetic and spelling skills. Students' speech will also be enriched with new words.

3. What word can be formed by substituting one consonant for another in the words

${ }^{2}$ Yo'ldosheva D. Ona tili ta'limi maqsadining tadrijiy taraqqiyoti. - T.: “O'zbekiston Milliy ensiklopediyasi" State scientific publishing house, 2019. daho, paxta, amal? Speak with each pair of words.

4. Students strengthen their phonetic and spelling knowledge by finding new words (daho-baho, paxta-taxta, amal-asal). By making sentences, they can clearly feel the difference between the meanings of the words. Develops the ability to use words correctly in speech.

5. Make sentences based on the given words. Gulzor, Ulug'bek, termoq, gul.

6. In doing so, students learn to connect words, both grammatically and semantically, to form sentences.

7. Write a text of 3-4 sentences about "heaven".

Creative work plays an important role in developing students' speaking, reasoning, and fluency skills. Therefore, this type of creative exercise should be done from the 1 st grade.

For 2nd grade mother tongue textbook:

1. Write the words denoting the name, sign, quantity, movement of the person and thing in separate columns, continue the sequence of words independently.

Find words that have similar and opposite meanings to the word "beautiful."

2. Such exercises help to understand the subtleties of meaning between synonyms and use them in their own place in speech. At the same time, it helps to easily acquire grammatical knowledge about antonyms.

3. Create new phrases by replacing words in phrases like polite child, fruit of tree, sweet as honey with other words.

Through this exercise, students learn to form new phrases by understanding the lexical meaning of Uzbek words. They will also learn about the types of phrases and the means by 
which they are connected.

4. Make a sentence based on the given scheme.

$\sim \sim \sim \sim$

Based on this type of exercise, the student learns to form sentences that are grammatically and semantically correct using their own vocabulary.

5. Speak. Use words that describe a person, a character, a quantity, or an action.

This type of exercise develops students' morphological and syntactic knowledge. Teaches the proper use of words in speech creation.

6. Write the name of the fruit in the picture together with their characteristic symbol.

The teaching of such exercises in textbooks helps to develop in students the qualities of sensitivity and sensitivity. As well as strengthening their morphological knowledge, it gives the student an initial understanding of the phrase.

7. Find the title of the story, replacing the words in the story.

Kamol bahorda bog'ga gilos ko'chatini ekdi. Daraxt juda ko'p hosil berdi.

Nihol ikki yildan so'ng daraxt bo'ldi. Doim niholning tagini yumshatib, suv quyib, uni parvarish qildi. Daraxt mevasidan bahramand bo'lgan insonlar Kamolning mehnatidan minnatdor bo'lishdi. Kamol daraxtning mevasidan qo'shnilarga ham berdi.

For 3rd grade mother tongue textbook:

1. Make a sentence using five nouns, both singular and plural.

Such exercises serve to develop skills such as learning the specific grammatical features of word groups and using them correctly in speech.

2. Use the words bosh, yog', onam in the plural. Explain the meaning of the words in this sentence. Keep finding words like this.
By doing such exercises, you will gain knowledge about the expressive meanings of the plural suffix "-s" and develop the ability to use it appropriately in speech.

3. Make a sentence with an affirmative verb. Using the negative form of this verb, explain the difference between the meanings of the sentences.

Such exercises strengthen the knowledge of the grammatical features of affirmative and negative verbs, their use in speech.

4. Make sentences using the numbers six and eleven in the form of cardinal numbers and ordinal numbers.

By doing this exercise, students will learn the difference between the types of meanings of numbers and how to use them correctly in a speech context.

5. Write a word for a group of five nouns that do not accept the plural suffix "-lar".

Through this exercise, students will understand the difference between countable and uncountable horses. The student develops the ability to use supplements appropriately.

6. Make horses with the suffixes "-chi", "-zor", "kor",

This exercise develops the student's ability to form new words and forms the quality of word differentiation.

For 4th grade mother tongue textbook:

1. Create a new word by changing the single sound of the words mart, mashshoq, xol, asil, asir.

By doing such exercises, students will gain a basic knowledge of paronyms and learn to use them appropriately in speech.

2. Explain the meaning of the word "sweet" in the phrase sweet grape and sweet child. Keep finding pairs of phrases like this. 
Through this type of exercise, students learn that words can have a figurative meaning in many places in addition to their original meaning. At the same time, they learn that using them in a conversational setting can make speech more engaging and effective. Such exercises play an important role in helping to understand the meaning of the words used in people's speech and grasp the essence of the idea that people are trying to convey.

3. Write a short story using the words mountain, tulip, hawthorn, travel.

The main goal of mother tongue education is to develop students' thinking and teach them to express themselves clearly and concisely. Assignments such as storytelling and writing can be a great help. Composing a story with the help of given words develops the student's creativity, grammar, and the ability to create a wellstructured text.

4. Make sentences with the words: beautiful, cold and good. Explain the purpose of the words in the sentences.

Students will learn about the grammatical features of adjectives.

5. The student is asked to write a conclusion based on the story read.

In the process of writing a summary, she learns to use the grammar knowledge she has acquired in her native language teaching. Develops the ability to express one's independent thoughts clearly and fluently in writing and orally. The student's worldview expands and he learns to draw the right conclusions.

\section{Conclusion}

In order to fully understand the meaning of each word in our language and to develop the ability to use them correctly in the right places, it is necessary to form in the student the qualities of creativity and independent thinking. Exercises in mother tongue textbooks play an important role in this. The use of cognitive-pragmatic methods in teaching language materials in primary school mother tongue textbooks increases the effectiveness of education. It is up to the system of exercises in the textbook to ensure that students can easily master the system of knowledge they need to master and apply it in practice. For this reason, giving more creative exercises in the textbook is an important step towards achieving the desired learning outcome.

\section{REFERENCES}

1. Gulomov A., Nematov H. Ona tili ta'limi mazmuni. - T.: "O'qituvchi" publishing house, 1995.

2. Fuzailov S., Xudoyberganova M., Yuldosheva Sh. Ona tili. Umumiy o'rta ta'lim maktablarining 3-sinfi uchun darslik. - T.: “O'qituvchi” publishing house, 2019.

3. Ikromova R., Gulomova X., Yuldosheva Sh., Shodmonqulova D. Ona tili. Umumiy o'rta ta'lim maktablarining 4-sinfi uchun darslik. T.: “O'qituvchi” publishing house, 2017.

4. Qosimova K., Fuzailov S., Nematova A. Ona tili. Umumiy o'rta ta'lim maktablarining 2sinfi uchun darslik. - T.: "O'qituvchi" publishing house, 2018.

5. Yuldosheva D. Ona tili ta'limi maqsadining tadrijiy taraqqiyoti. - T.: "O'zbekiston Milliy ensiklopediyasi" State scientific publishing house, 2019.

6. G'afforov T., Shodmonov E., G'ulomova X. Ona tili. Umumiy o'rta ta'lim maktablarining 1sinfi uchun darslik. - T.: Sharq, 2019. 